\title{
Implikasi Penyalagunaan Wewenang Administrasi Dalam Seleksi Perangkat Desa Kabupaten Demak
}

\author{
Muhamad Azhar \\ Dosen Hukum Administrasi FH UNDIP \\ Fakultas Hukum, Universitas Diponegoro
}

\begin{abstract}
This study aims to find out how the implications of the abuse of Administrative Authority in the Village Apparatus Selection in Demak Regency. The research is a concise study based on cases that were consulted at the Legal Consultation Board, Faculty of Law, University of Diponegoro. Research Results Aimed that the abuse of authority occurred in the process of selecting village officials in Demak Regency. The authority to determine the selection committee of the village apparatus is the authority of the Village Head as mandated by the Law - Invitation on the Village, and not the authority of the Regent of Demak Regency.
\end{abstract}

Keywords: Power Utilization, Village Officials, Demak Regency.

\begin{abstract}
Abstrak
Penelitian ini bertujuan untuk mengtahui bagaimana implikasi penyalagunaan Wewenang Administrasi Dalam Seleksi Perangkat Desa di Kabupaten Demak. Penelitian merupakan kajian ringkas berdasarkan pada kasus yang dikonsultasikan pada Badan Konsultasi Hukum, Fakultas Hukum Universitas Diponegoro. Hasil Penelitian Menujukan bahwa penyalagunaan wewenang terjadi pada proses seleksi perangkat desa di Kabupaten Demak. Kewenangan untuk menetapkan panitian seleksi perangkat desa merupakan kewenangan dari Kepala Desa sebagaimana amanat Peraturan Perundang - Undangan tentang Desa, dan bukan berada pada kewenangan Bupati Kabupaten Demak.
\end{abstract}

Kata Kunci: Penyalagunaan Wewenang, Perangkat Desa, Kabupaten Demak.

\section{A. Pendahuluan.}

Dugaan kuat ${ }^{1}$ adanya pelanggaran terhadap seleksi perangkat desa Kabupten Demak ditanggapi Serius oleh dewan perwakilan daerah (DPRD) Kab. Demak. Tanggapan serius ini tentu saja dilakukan dengan cara-cara sebagaimana tugas dan fungsi pokok DPRD Kabupaten Demak. Melihat pekermbangan isu dugaan pelanggaran dalam ${ }^{\text {proses }}$ seleksi perangkat desa tersebut, maka DPRD Kabuaten Demak ingin memastikah, apakah penggunaan Hak Angket oleh DPRD sudah tepat, dalam rangka mencari solusi atas dugaan "pelanggaran" proses

\footnotetext{
${ }^{1}$ Laporan DPRD.
} 
seleksi perangkat desa? Lalu bagaimana pula solusi yang tepat bagi DPRD untuk mengakomodir aspirasi rakya yang berkembang.

Untuk menguraikan "Implikasi Penyalagunaan Wewenang Administrasi dalam Seleksi Perangkat Desa Kabupaten Demak" dan menjawab, pertanyaan penting tersebut, maka terlebih dahulu diuraikan beberapa hal terkait dengan pertanyaan tersebut, diantara uraian tersebut adalah 1). Wewenang administrasi; 2). Tugas dan fungsi DPRD dalam pelaksanaan pemerintahan di Daerah; dan 3). Penggunaan hak angket dan implikasinya terhadap perbuatan pemerintah. Sebagai penutup dari pendapat ini sedikit diuraikan simpulan secukupnya.

\section{B. Wewenang Administrasi dalam Pelaksanaan Selekai Perangkat Desa.}

Wewenang atau kewenangan sering disejajarkan dengan istilah Belanda "bevoegdheid" (wewenang atau berkuasaan). Wewenang merupakan bagian yang sangat penting dalam perbuatan pemerintah. Bagir Manan, menyatakan wewenang diartikan kekuasaan menggambarkan hak untuk berbuat atau tidak berbuat. Wewenang mengandung arti hak dan kewajiban. Hak berisi kebebasan untuk melakukan atau tidak melakukan tindakan tertentu atau menuntut pihak lain untuk melakukan tindakan tertentu. Kewajiban memuat keharusan untuk melakukan atau tidak melakukan tindakan tertentu

Dalam hukum administrasi negara wewenang pemerintahan yang bersumber dari peraturan perundang-undangan diperoleh melalui caracara yaitu atribusi (original legislator atau delegated legislator), delegasi dan mandat. Selain itu juga, dikenal mengenai kapan suatu ketidakwenangan aparat, apa penyebab aparat tidak berwenang (onbevoegdheid) itu terjadi. Tidak wewenang (onbevoegdheid atau bevoeghedsgebreeken) jika memenuhi tiga keadaan yakni ratione material, ratione loccus, dan ratione temporis.

Wewenang dalam melakukan seleksi perangkat desa Kabupaten Demak merujuk pada Peraturan Daerah Kabupaten Demak Nomor 6 Tahun 2015 Tentang Perangkat Desa. Seleksi perangkat desa dilakukan oleh Panitia Pengangkatan Perangkat Desa atau juga dikenal dengan istilah Panitia Pengangkatan dalam aturan tersebut. Panitia pengangkatan dibentuk oleh Kepala Desa yang keanggotaannya terdiri dari anggota BPD dan Perangkat Desa yang bertugas menyelenggarakan kegiatan-kegiatan yang berkaitan dengan pelaksanaan pencalonan dan pengangkatan Perangkat Desa. Dengan demikian bahwa maka dapat 
dimengerti bahwa kewenangan melakukan seleksi adalah berada pada Panitia Pengangkatan Perangkat Desa, kewenangan yang didapatkan secara atribusi melalui delegated legislator.

Dalam menjalankan tugas, Panitia Pengangkatan Perangkat Desa dapat melibatkan pihak lain, dalam hal ini adalah institusi pendidikan. Intitusi yang dimaksud adalah perguruan tinggi dengan sekurang kurangnya terakreditasi B. Dalam menjalankan wewenang tersebut, Panitia Pengangkatan Perangkat Desa Kabupaten Demak melibatkan pihak lain dalam melakukan seleksi. Dalam hal ini adalah Universitas Indonesia, Universitas Diponegoro dan Universitas Negeri Sebelas Maret. Penunjukan pihak lain merupakan amanat dari Peraturan Daerah Kabupaten Demak Nomor 6 Tahun 2015 Tentang Perangkat Desa. Keterlibatan tersebut tidak bersifat absolut, atau mutlak. Jika keterlibatan pihak kedua tersebut justru mengakitakan tidak terbukannya proses seleksi maka keterlibatan pihak lain menjadi tidak penting. Keterlibatan pihak lain dalam proses seleksi seyogyanya untuk menciptakan proses yang objektif dalam proses seleksi.

Berdasarkan laporan yang disampaikan kepada penulis, bahwa terdapat ada dugaan pelanggaran dari panitia seleksi terkait dengan proses seleksi tersebut. namun tidak disebutkan secara jelas bagaian mana pelanggaran tersebut dilakukan. Hak Angket adalah hak DPRD untuk melakukan penyelidikan terhadap kebijakan pemerintah daerah yang penting dan strategis serta berdampak luas pada kehidup-an bermasyarakat dan bernegara yang diduga bertentangan dengan ketentuan peraturan perundang-undangan.

\section{Simpulan}

Hasil Penelitian Menujukan bahwa penyalagunaan wewenang terjadi pada proses seleksi perangkat desa di Kabupaten Demak. Kewenangan untuk menetapkan panitian seleksi perangkat desa merupakan kewenangan dari Kepala Desa sebagaimana amanat Peraturan Perundang - Undangan tentang Desa, dan bukan berada pada kewenangan Bupati Kabupaten Demak.

\section{Daftar Pusataka}

Adrian Sutedi, Hukum Perizinan Dalam Sektor Pelayanan Publik, Sinar Grafika, Jakarta, 2010

Agus Dwiyanto, Mewujudkan Good Governance melalui Pelayanan Publik, Gadjah Mada University Press, Yogyakarta, 2005.

Juniarso Ridwan dan Achmad Sodik Sudrajat, Hukum Administrasi Negara dan Kebijakan Pelayanan Publik, Penerbit Nuansa, Bandung, 2009.

Nomensen Sinamo, Hukum Administrasi Negara, Jala Permata Aksara, Jakarta, 2010 
Nuryanto A. Daim, Hukum Administrasi - Perbandingan Penyelesaian Maladministrasi Oleh Ombudsman dan PTUN, Laksbang Justisia, Surabaya, 2014

Nuriyanto, Penyelenggaraan Pelayanan Publik di Indonesia, Sudahkah Berlandaskan Konsep

Welfare State?, Jurnal Konstitusi, Vol.11 Nomor 3, September 2014

Philipus M Hadjon, Pemerintahan Menurut Hukum (wet en rechtmatig Bestuur), Yuridika Surabaya, 1993

Philipus M Hadjon, Fungsi Normatif Hukum Administrasi dalam menuju Pemerintahan yang Bersih, Pidato Pengukuhan Guru Besar di Unair, 1994.

Philipus M Hadjon et al, Pengantar Hukum Administrasi Indonesia (Introduction to the Indonesian Administrative Law), Gadjah Mada University Press Yogyakarta, 2011.

Philipus M Hadjon, Hukum Administrasi dan Tindak Pidana Korupsi, Gajah mada University Press, Yogyakarta, 2011

Sadu Wasistiono, Penyelenggaraan Pemerintahan Daerah, Fokusmedia, Bandung, 2003 UU No.25 Tahun 2009 tentang Pelayanan Publik

UU No.30 Tahun 2014 tentang Administrasi Pemerintahan 